\title{
Orang Tua Kreatif untuk Anak Usia Dini di Masa Pandemi Covid-19 Melalui Kegiatan Parenting
}

\author{
Nur Anisyah"1 ${ }^{1}$ Indrawati ${ }^{2}$, Latansa Hafizotun ${ }^{3}$, Siti Marwah ${ }^{4}$, Vivi Yumarni'5 , Nurul Annisa DN6 \\ 1,2,3,4,5,6 STAI Ma'rif Jambi \\ e-mail: anisyahsuid12jmb@gmail.com
}

\begin{abstract}
ABSTRAK. Penelitian ini bertujuan untuk mengetahui bagaimana menjadi orang tua yang kreatif dalam mendampingi anak usia dini dimasa pandemic covid-19 melalui kegiatan parenting. Penelitian ini merupakan penelitian deskripstif kualitatif. Adapun subjek penelitian ini adalah orang tua, guru dan siswa-siswi PAUD Ungu Dusun Lubuk Landai Kecamatan Tanah Sepenggal Kabupaten Bungo Provinsi Jambi. Penentuan subjek penelitian ini diambil karena informan itu telah memenuhi syarat kesesuaian terhadap penelitian yang sedang dilaksanakan. Hasil penelitian ini adalah dengan dilakukannya 2 tahapan kegiatan yaitu tahap pertama berupa kegiatan parenting dan tahap kedua adalah dilakukannya kegiatan lomba kreatifitas ibu dan anak, maka didapatkan suatu kesimpulan bahwa dari 2 tahapan kegiatan ini dapat mendukung dan menciptakan orang tua yang kreatif untuk anak usia dini dimasa pandemic covid-19. Hal ini dibuktikan dengan begitu antusias dan semangatnya orang tua, guru dan siswa-siswi dalam mengikuti kegiatan parenting dan lomba yang diadakan oleh peniliti tim pengabdian masyarakat dari STAI Ma'arif kota Jambi. Diperlukan panduan dari orang tua agar menjadi kreatif dalam memenuhi kebutuhan pengajaran pada anak-anak usia dini, dalam hal ini bisa dilakukan oleh pihak sekolah yaitu melalui kegiatan parenting
\end{abstract}

Kata Kunci : Parenting, Orang Tua Kreatif, Anak Usia Dini, Masa Pandemi.

ABSTRACT. This study aims to find out how to be creative parents in accompanying early childhood during the Covid-19 pandemic through parenting activities. This research is a qualitative descriptive study. The subjects of this study were parents, teachers and students of PAUD Ungu Lubuk Landai Hamlet, Tanah Sepenggal District, Bungo Regency, Jambi Province. The determination of the subject of this study was taken because the informant had met the suitability requirements for the research being carried out. The result of this research is that by carrying out 2 stages of activity, namely the first stage in the form of parenting activities and the second stage is carrying out the activities of the mother and child creativity competition, it is concluded that from the 2 stages of this activity can support and create creative parents for early childhood in the future. the covid-19 pandemic. This is evidenced by the enthusiasm and enthusiasm of the parents, teachers and students in participating in parenting activities and competitions held by community service researchers from STAI Ma'arif, Jambi City. Guidance from parents is needed to be creative in meeting the teaching needs of early childhood, in this case it can be done by the school, namely through parenting activities

Keyword : Parenting, Creative Parents, Early Childhood, Pandemic Period 


\section{PENDAHULUAN}

Pada saat terjadinya wabah COVID-19, pemerintah melalui Kementrian Pendidikan Nasional mengeluarkan kebijakan sebagai respon terhadap adanya pandemi COVID-19. Seluruh institusi pendidikan, dari tingkatan paling bawah sampai Perguruan Tinggi diinstruksikan untuk mengganti pembelajaran tatap muka dengan pembelajaran online/daring akibat adanya wabah COVID-19. Dengan situasi seperti itu, para orang tua dituntut untuk dapat dengan kreatif memberikan pendampingan dan bimbingan dalam pembelajaran anak yang dilakukan di rumah atau istilahnya belajar dari rumah (BDR) [1]. Orang tua yang kreatif harus merangsang anak-anak usia dini untuk tertarik mengamati dan mempertanyakan tentang berbagai benda atau kejadian di lingkungan sekitar. Orang tua pun juga harus banyak baca dan belajar agar mampu menjawab setiap keingintahuan si anak. Penyediaan sarana untuk merangsang si anak berpikir lebih dalam juga perlu, misalnya dengan memberikan gambar-gambar, buku-buku. Jangan menolak, melarang atau menghentikan rasa ingin tahu si anak, asalkan tidak membahayakan dirinya atau orang lain. Sejatinya orang tua harus menjadi figur dalam memberi kesabaran pada anak, hal lain menunjukkan bahwa ternyata orang tua juga sudah merasa jenuh dengan pembelajaran yang dilakukan dirumah serta WFH yang di terapkan hal itu memicu ketidaksabaran orang tua dalam menemani anak belajar dan bermain[2].

Orang tua juga butuh suatu sharing atau berbagi ilmu mengenai cara menjadi pendidik yang kreatif yang mana bisa didapatkan para orang tua melalui kegiatan parenting dari sekolah. Menyinggung tentang kreatifitas perkembangan peserta didik merupakan suatu yang sangat menarik. Hal itu disebabkan karena potensi dari kreatifitas yang terdapat pada diri peserta didik. Adanya berbagai macam potensi dan kreatifitas pada diri peserta didik pastinya tidak muncul begitu saja, tetapi banyak faktor yang menjadi penyebab, seperti lingkungan yang merupakan faktor psikososial yang berpengaruh pada perkembangan kreatifitas peserta didik. Untuk membentuk anak yang kreatif dimasa pandemik ini, maka dibutuhkan juga orang tua yang kreatif dalam membimbing dan mendampingi anak-anak belajar dari rumah. Orang tua merupakan seseorang yang melahirkan kita atau orang tua biologis. Namun orang tua juga tidak selalu dalam pengertian yang melahirkan. Orang tua juga bisa terdefinisikan terhadap orang tua yang telah memberikan arti kehidupan bagi kita. Orang tua yang telah mengasihi kita, memelihara kita sedari kecil. Orang tua disini memiliki peran penting dalam pendidikan anak, karena madrasah pertama seorang anak adalah dalam lingkungan keluarganya terutama anak mendapatkan pengajaran dan pembelajaran yang utama adalah dari pihak orang tua.

Parenting adalah cara mengasuh dan mendidik anak. Anda tentu sudah sangat sering mendengar istilah ini kehidupan sehari-hari. Banyak program parenting saat ini yang bisa diikuti oleh orangtua. Program parenting adalah salah satu upaya untuk meningkatkan kualitas pola asuh orangtua guna membangun karakter positif pada anak. Parenting adalah bagaimana cara mendidik orangtua terhadap anak baik secara langsung maupun tidak langsung. John W, Santrock mengemukakan bahwa pengasuhan (parenting)membutuhkan sejumlah kemampuan interpersonal dan mempunyai 
tuntutan interpersonal yang besar, tetapi sangat sedikit dalam pendidikan formal mengenai tugas ini[3]. Pola pengasuhan tergantung dari bagaimana suatu lingkungan keluarga membentuk aturan (perilaku, norma dan nilai) yang harus dipatuhi oleh anggota keluarganya. Parenting menyangkut semua perilaku orangtua sehari-hari baik yang berhubungan langsung dengan anak maupun tidak, yang dapat ditangkap maupun dilihat oleh anak-anaknya, dengan harapan apa yang diberikan kepada anak (pengasuhan) akan berdampak positif bagi kehidupannya terutama bagi agama, diri, bangsa, dan juga negaranya. Hal sesuai hasil penelitian Aris yang menyimpulkan bahwa Pada masa pandemi covid 19 PAUD menyelenggerakan pendidikan dengan media online (whatsapp group bersama orang tua anak). Materi penanaman nilai pendidikan Islam tetap diberikan[4]. Hasil penelitian lain oleh Rahmadani menyimpulkan bahwa orang tua mengkondisikan lingkungan keluarga sebaik mungkin untuk menunjang pendidikan anak, hal ini dibuktikan dengan diputarkan ayat-ayat Al-Qur'an setiapmalam, orang tua selalu meluangkan waktu untuk anak dan komunikasi yang baik dalam keluarga[5].

Secara bahasa parenting berasal dari bahasa Inggris, dari kata Parent yang berarti Orang tua [6]. Sedangkan dalam kamus Oxford Parenting adalah the process of caring for your child or children. Secara terminologi, parenting dapat didefinisikan sebagai proses mengasuh anak-anak. Didalam bahasa Indonesia kata mengasuh mengandung makna sebagai metode atau cara orang tua mencukupi kebutuhan fisiologis dan psikis, mendidik dan mengajar anak agar memiliki pengetahuan dan keterampilan serta menanamkan norma, nilai rohani dan bagaimana berinteraksi atau bersosialisai dengan lingkungan. Secara ringkas, parenting anak-anak dapat digambarkan sebagai rangkaian tindakan, perbuatan dan interaksi dari orang tua untuk mendorong pertumbuhan dan perkembangan anak-anak agar mereka tumbuh dan berkembang sesuai dengan pola asuh yang baik dan benar [7].

Mengingat parenting bukanlah kegiatan satu pihak dari orang tua tetapi juga dari sekolah. Apabila menginginkan keberhasilan dalam proses pendidikan dan pengasuhan anak usia dini, maka perlu adanya keterlibatan. Program parenting adalah program pendidikan yang diberikan kepada orang tua agar pengetahuan yang dimiliki orang tua menjadi bertambah tentang tumbuh kembang anak serta agar pendidikan yang diperoleh anak selaras antara di rumah dan di sekolah [8]. Proses pendidikan dan pengasuhan didalam keluarga yang dilakukan oleh orang tua terutama ayah dan ibu dimulai sejak dalam kandungan, yakni sejak masa embrio terjadi. Proses pendidikan pada masa sejak dalam kandungan dapat dilihat dari perilaku orang tua. Mereka menjaga tuturan, pikiran dan prilaku karena percaya semua yang dilakukan berimbas pada sang janin. Perhatian dan kasih sayang juga pendidikan dan bimbingan yang dilakukan orang tua bisa dilakukan dengan mengajak janin berbicara, mendengarkan musik dan memberinya cerita. Keyakinan ini didukung pendapat dan penelitian para ahli mengenai efek gelombang dan suara sebagai perangsang pertumbuhan dan kecerdasan janin [9].

Mengacu pada kata dasar orang tua dan parenting diatas, maka upaya dan langkah nyata dalam bentuk kegiatan parenting sebagai wujud kegiatan pengabdian perlu dilakukan sehingga kreatifitas orang tua dan guru dalam pembelajaran daring 
anak usia dini dapat dipahami dan ditingkatkan orang tua dan guru di PAUD. Karena kurangnya pemahaman orang tua dan guru menyebabkan pelaksanaan pembelajaran anak usia dini selama covid 19 sangat rendah. Kristiana mengungkapkan bahwa perlunya kerjasama dengan pihak orang tua dengan melakukan komunikasi efektif berkaitan dengan kegiatan pembelajaran yang dilakaukan selama pembelajaran dari rumah karena pelaksana kegiatan adalah orang tua. Kegiatan dapat berupa perencanaan yang telah dirancang dari lembaga ataupun kegiatan yang dilakukan bersama orang tua di rumah. Kegiatan yang diberikan lebih kepada pengembangan keterampilan hidup dan karakter anak[10]. Salah satu upaya yang dapat dilakukan untuk memberikan pengetahuan dan pemahaman kepada orang tua mengenai pembelajaran daring selama covid 19 dengan melakukan kegiatan parenting mengangkat tema menjadi orang tua kreatif untuk anak usia dini di masa pandemi covid 19.

\section{METODE}

Metode pelaksanaan program pengabdian masyarakat dilaksanakan dalam beberapa tahap yaitu: tahapan perencanaan, tahapan pelaksanaan dan tahapan evaluasi. Tahapan perencanaan telah ditetapkan dengan menentukan lokasi pengabdian yang berlokasi di PAUD Ungu dusun lubuk landau kecamatan tanah sepenggal. Jenis kegiatan adalah workhsop parenting dengan Tema " menjadi orang tua kreatif untuk anak usia ini di masa pandemi”. Tahapan pelaksanaan berupa kegiatan seminar parenting kemudian dilanjutkan dengan workshop dengan bentuk lomba kreatifitas ibu dan anak yang berkolaborasi dengan pengelola dan guru PAUD Ungu Dusun Lubuk Landai kecamatan tanah sepenhhal kabuten bungo dalam program pengabdian kepada masyarakat.

Kegiatan pengabdian pada masayrakat menggunakan metode dalam bentuk seminar dan Workhsop dalam bentuk lomba kreatifitas ibu dan anak yang dilaksanakan di Lembaga PAUD Ungu. Adapun tahapan-tahapan dalam pelaksanaan kegiatannya berupa seminar, demonstrasi, tanya jawab dan simulasi mengenai masalah kreatifitas orang tua. Kelayakan sasaran yang strategi untuk masalah ini adalah guru pendidik anak usia dini, orang tua yang memiliki balita. Dipilihnya sasaran kegiatan pengabdian ini adalah karena pesertanya memiliki potensi untuk dapat mengembangkan program pendidikan parenting secara praktis dan memiliki potensi untuk dapat dijadikan sebagai agen perubahan dalam pendekantan pendidikan orang tua terhadap anaknya di keluarga pada umummya dan di dusun lubuk landai kecamatan tanah sepenggal kabupaten bungo. Tingkat pencapaian dari kegiatan pengabdian kepada masayarakat ini adalah melalui pengamatan langsung serta simulasi pada peserta dalam proses persiapan, pelaksanan dan evaluasi dalam pendampingan yang dilakukan sehingga dapat memberikan gambaran mengenai capaian yang telah diperoleh oleh peserta terhadap pendidikan anak usia dini yang di jalankan. 


\section{HASIL DAN PEMBAHASAN}

Pembahasan hasil penelitian dimulai dari observasi, wawancara dan dokumentasi. Data yang telah diperoleh dari hasil observasi, wawancara dan dokumentasi selanjutnya di telaah dan dianalisis. Dalam penelitian yang peneliti lakukan peneliti menganalisis apapun yang berkenaan tentang kegiatan pelaksanaan kegiatan parenting menjadi orang tua kreatif untuk anak usia dini diantaranya:

\section{a. Pelaksanaan Kegiatan Parenting PAUD Ungu Dusun Lubuk Landai Kecamatan Tanah Sepenggal}

Sebelumnya PAUD Ungu sudah membuat program parenting yang telah disusun selama 5 tahun terakhir yakni tema memahami golden age pada anak usia dini, anakku susah belajar, emosi anak versi emosi orang tua, memahami gizi anak dan memahami karakter anak. Hal tersebut sesuai dengan hasil wawancara peneliti dengan Bapak Abdul Mukti selaku pimpinan PAUD Ungu. Dalam wawancaranya berisi sebagai berikut: PAUD Ungu ini sudah 8 tahun didirikan dan program parenting telah disusun 5 terakhir ini namun satupun tidak ada yang terlaksana, kendalanya karena saya sendiri dan para guru belum memahami sepenuhnya bagaimana pelaksanaan kegiatan parenting ini. Hal yang sama juga diungkapkan oleh ibu Afriani selaku kepala sekolah PAUD Ungu : "Iya benar program parenting di PAUD Ungu belum pernah terlaksana sesuai dengan program yang telah direncanakan, orang tua hanya pernah mengikuti kegiatan parenting yang diadakan oleh kecamatan jadi kegiatan parentingnya dilaksanakan serentah sekecamatan tanah sepenggal semua PAUD kecamatan tanah sepenggal berkumpul pada acara tersebut itupun sudah lama dilaksanakan bulan oktober 2018 lalu setelah itu tidak ada lagi kegiatan parenting. Menurut Heru Kurniawan bahwa jenisjenis program Parenting yang dapat dilaksanakan untuk lembaga-lembaga PAUD, diantaranya: 1) Parents Gathering. Parents Gatering adalah pertemuan orang tua dengan pihak lembaga PAUD yang difasilitasi oleh panitia program Parenting guna membicarakan tentang program-program lembaga PAUD dalam hubungannya dengan bimbingan dan pengasuhan anak di keluarga dalam rangka menumbuh-kembangkan anak secara optimal. Materi dalam pertemuan dapat berbagai hal tetang kebutuhan tumbuh- kembang anak, misalnya: tentang gizi dan makna, tentang kesehatan, tentang pendidikan karakter, penyakit pada anak, dan sebagainya; 2) Foundation Class. Foundation Class adalah pembelajaran bersama anak dengan orangtua di awal masuk sekolah dalam rangka orientasi dan pengenalan kegiatan sekolah. Dilaksanakan pada minggu-minggu pertama anak-anak mulai masuk sekolah di tahun ajaran baru; 3) Seminar. Seminar adalah kegiatan dalam rangka program parenting, yang dapat dilaksanakan dalam bentuk kegiatan seminar. Misalnya dengan mengudang tokoh atau praktisi PAUD yang kompeten, pakar dongeng, phisikolog, dan lain-lain; 4) Hari Konsultasi. Hari Konsultasi adalah hari dengan kegiatan pertemuan konsultasi untuk orang tua yang dapat disediakan atau di buka oleh lembaga PAUD. Jumlah hari yang disediakan sesuai dengan tinggi rendahnya kasus atau jumlah orang tua yang melakukan konsultasi; 5) Field Trip. Field Trip adalah darmawisata, kunjungan wisata, atau kunjungan ke tempat-tempat yang menunjang kegiatan pembelajaran PAUD. Kegiatan kunjungan dilakukan bersama dengan orang tua. Misalnya kunjungan ke 
museum, kunjungan ke bandar udara, pelabuhan, atau tempat-tempat lain yang sesuai dengan tema dalam pembelajaran; 6) Home Activities. Home Activities adalah aktivitas di rumah dibawa ke sekolah, yaitu membawa orang tua untuk menginap di sekolah. Hal tersebut bisa dilakukan dengan kegiatan perkemahan di lapangan apabila di sekolah tidak mampu menyediakan tempat menginap. Kegiatan yang dilaksakan adalah bimbingan bagaimana kegiatan dirumah yang baik untuk mendidik anak, dan menciptakan situasi yang kondusif untuk anak di rumah; 7) Cooking on The Spot. Cooking on The Spot adalah anak-anak belajar menyiapkan masakan, menyajikan makanan dengan bimbingan guru atau bersama dengan orang tua; 8) Bazar Day. Bazar Day adalah menyelenggarakan bazar di lembaga PAUD, Anak-anak menampilkan karyanya yang dijual pada orang tua atau umum; 9) Mini Zoo. Mini Zoo adalah menyelenggarakan kebun binatang mini di sekolah, yaitu anak-anak membawa binatang kesayangannya atau binatang peliharaannya di rumah ke lembaga PAUD; dan 10) Home Education Video. Home Education Video adalah mengirimkan rekaman kegiatan pembelajaran anak-anak di lembaga PAUD pada orang tua dalam bentuk keping CD/DVD, agar dapat disaksikan dan dipelajari juga orang tua di rumah[11].

Dari hasil wawancara yang peneliti lakukan kepada pimpinan PAUD Ungu dan kepala sekolah PAUD Ungu dapat disimpulkan bahwa kegiatan parenting di PAUD Ungu baru pertama kali ini dilaksanakan dari kegiatan pengabdian kepada masyarakat dosen pendidikan islam anak usia dini Stai Ma'arif Jambi. Kegiatan parenting menjadi orang tua kreatif untuk anak usia dini di masa pandemi covid 19 di PAUD Ungu Dusun lubuk landai sangat antusias dari orang tua dan guru karena hal ini merupakan kegiatan yang baru pertama kali mereka dapatkan. Wawancara dengan salah satu orang tua murid ibu dari Anaanda Shaqeena sebagai berikut: "Saya peribadi dan orang tua murid yang mengikuti kegiatan parenting menjadi orang tua kreatif untuk anak usia dini sangat senang dan materi yang disampaikan sangat berguna bagi kami karena kami memang belum memahami cara membimbing dan mendidik anak kami yang berusia PAUD untuk melaksanakan pembelajaran dari rumah, alhamdulillah setelah kegiatan materi pada hari ini senin 28 desember 2020 kami sangat terbuka fikiran dan wawasan untuk mendampingi anak belajar daring selama covid 19 ini".

Hal ini sejalan dengan yang peneliti lihat dilapangan pada kegiatan parenting menjadi orang tua kreatif untuk anak usia dini di masa pandemi covid 19 dalam melaksanakan mejnadi orang tua kreatif untuk anak usia dini di masa pandemi covid 19 ada peluang yang sangat besar dan hampir tidak ada hambatan yang pasti di dalam pelaksanaanya dan orang tua sangat semangat untuk menerima materi yang akan disampaikan hal ini terlihat dari berbagai pertanyaan orang tua mengenai menjadi orang tua kreatif untuk anak usia dini di masa pandemi. Hasil penelitian oleh Andani menyatakan bahwa kesesuaian materi dalam pelaksanaan kegiatan parenting dapat terlihat antusias orangtua dalam mengikuti kegiatan parenting education, orangtua peserta didik aktif mengajukan pertanyaan, saran, dan pendapat untuk program parenting education selanjutnya. Orangtua aktif juga mengikuti kegiatan parenting education di luar lingkungan sekolah seperti wisata edukasi, outbond, dan kegiatan 
lainnya[12]. Sedangkan tujuan program parenting education dalam kesehatan dan gizi akan diupayakan melalui pengembangan materi yang menurut Direktorat Pembinaan Pendidikan Anak Usia Dini tahun 2012 mencakup enam bahasan, yaitu: 1. peningkatan gizi, 2. pemeliharaan kesehatan, 3. perawatan, 4. pengasuhan, 5. pendidikan, dan 6 . perlindungan. Enam materi di atas akan dijadikan poin dasar dalam kegiatan parenting education[13]. Antusias orang tua yang mengikuti kegiatan parenting ini dapat terlihat pada gambar 1 di bawah ini.
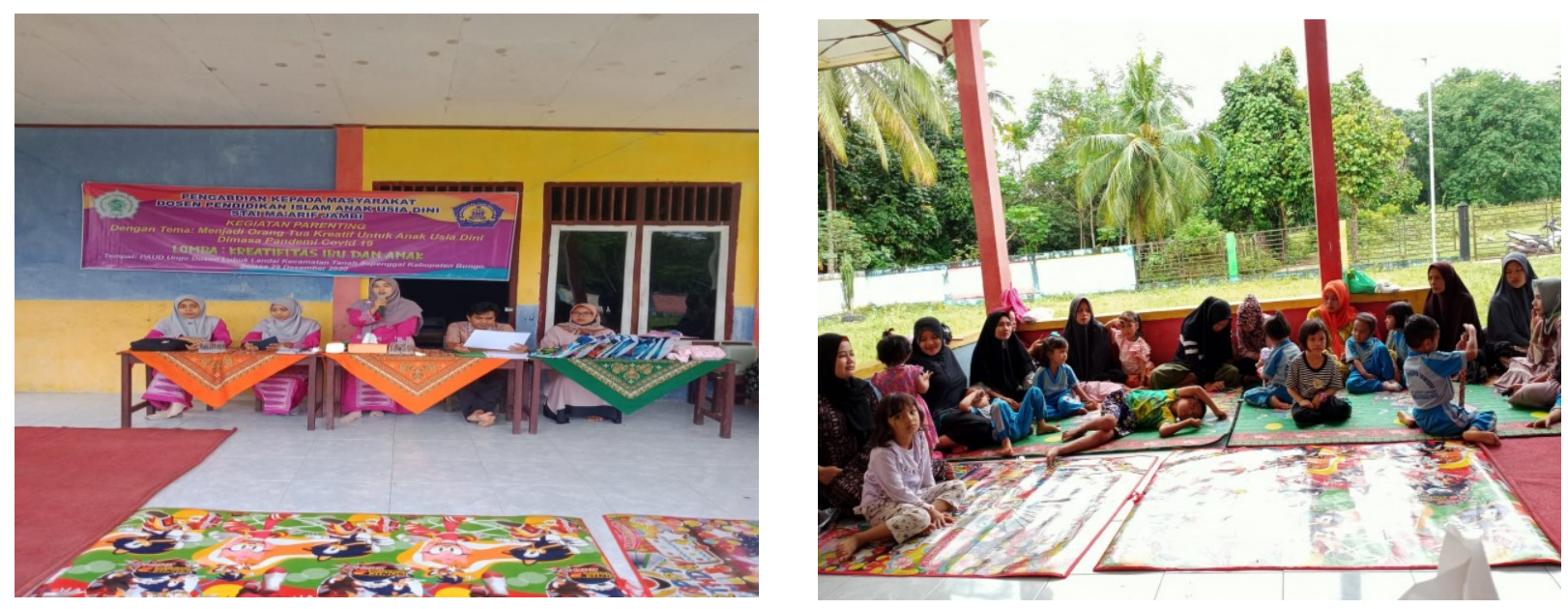

Gambar. 1 Kegiatan Parenting Di PAUD UNGU

\section{b. Pelaksanaan Lomba Kreatifitas Ibu Dan Anak PAUD Ungu Dusun Lubuk Landai Kecamatan Tanah Sepenggal}

Pelaksanaan lomba kreatifitas ibu dan anak sangat antusias di laksanakan oleh para ibu dan anak PAUD Ungu dusun lubuk landai kecamatan tanah sepenggal kabupaten bungo. Lomba dilaksanakan pada hari selasa tanggal 29 desember 2020 dengan perlombaan ini di harapkan ibu dan anak lebih kreatif dan termotivasi dan berkreasi serta tergali giat belajar selama masa pandemi covid 19. Lomba kreatifitas tersebut memperlihatkan kekompakan ibu dan anak mulai dari menggunting, menempel di sandal jepit hingga menjadi sebuah sandal yang indah melalui kerja sama yang menciptakan keakraban ibu dan anak. Lomba kreatifitas ibu dan anak ini merupakan bagian dari kegiatan parenting menjadi orang tua kreatif untuk anak usia dini di masa pandemi yang di ikuti oleh 25 orang tua. Kreativitas merupakan bagian dari kegiatan yang dapat menghasilkan suatu karya seni dan harus disesuaikan dengan kebutuhan, kemampuan dan minat anak. Hasil kreativitas berupa produk bukan merupakan tujuan yang terlalu penting, yang terpenting adalah bagaimana kegiatan yang dilakukan dengan kesenangan dapat menjadikan kegiatan yang menyenangkan sehingga anak tidak mudah cepat bosan[14]. Kreativitas anak usia dini dapat diupayakan melalui permainan yang dirancang oleh Pendidik di Lembaga PAUD, karena dengan permainan anak dapat mengembangkan serta mengintergrasikan semua potensinya, sehinga mereka lebih kreatif[15].

Wawancara dengan salah satu orang tua murid: "Kami sangat senang dengan adanya kegiatan lomba ini karena baru pertama kali menemukan kegiatan lomba seperti ini menjadi motivasi untuk kami orang tua dalam meningkatkan kreatifitas untuk 
membimbing anak dirumah belajar selama covid ini". Hal ini sesuai dengan hasil penelitian lain yang dilakukan oleh Yeni terkait pelaksanaan parenting mampu menjadikan salah satu jalan agar program makanan sehat ini dapat selalu berjalan dengan baik. selain itu dapat memberikan motivasi kepada semua pihak yang ikut bekerja sama dalam perlombaan ini dan dapat menumbuhkan kesadaran akan sayang kepada tubuh dengan menerapkan pola hidup sehat dimanapun berada[16]. Antusias anak dan orang tua dalam mengikuti lomba dapat dilihat pada gambar 2 di bawah ini.
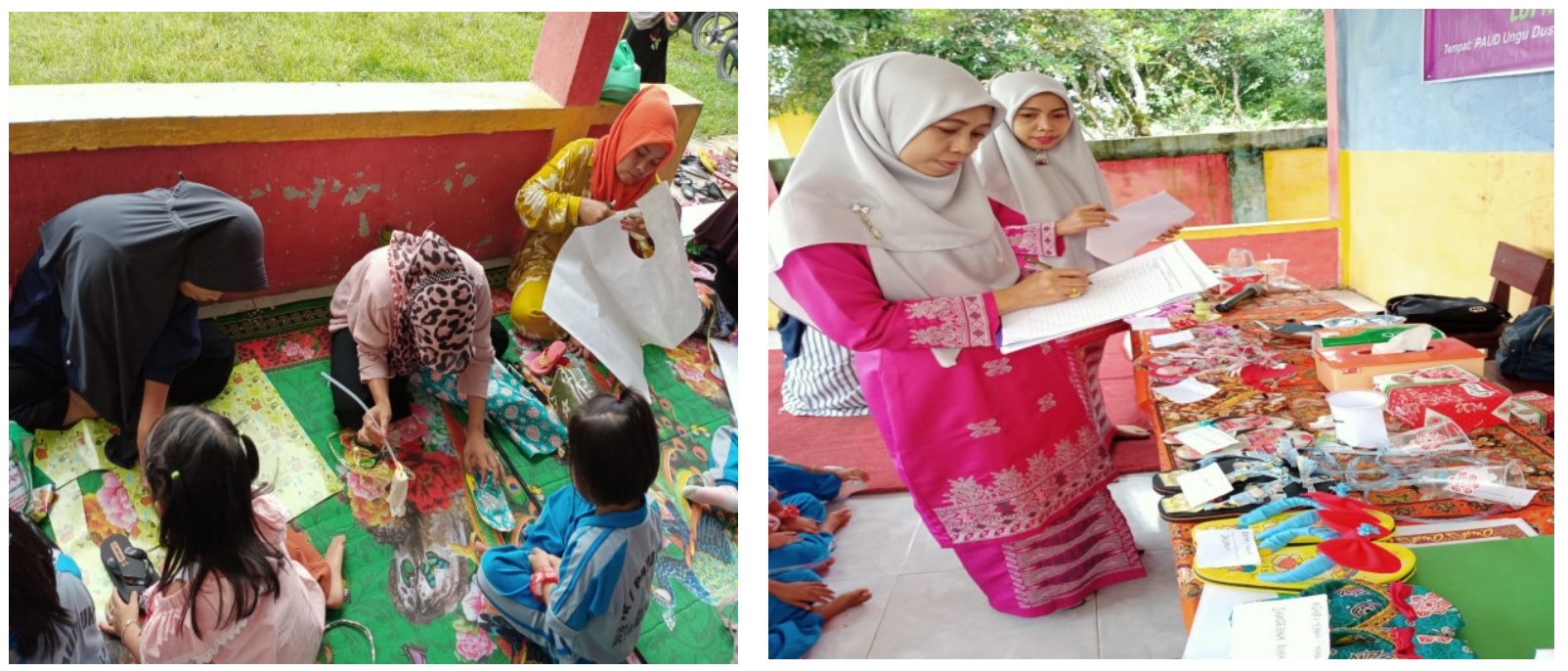

Gambar 2. Lomba Kreativitas Ibu dan Anak

Proses pembahasan hasil penelitian dimulai dengan menelaah seluruh data yang tersedia dari berbagai sumber hasil observasi/pengamatan langsung, wawancara dan dokumentasi. Pembahasan hasil penelitian juga berarti proses berkelanjutan selama penelitian langsung. Dalam penelitian ini peneliti memiliki analisis selama menjalankan penelitian tentang pelaksanaan kegiatan parenting menjadi orang tua kreatif untuk anak usia dini di masa pandemi covid 19 di PAUD Ungu Dusun Lubuk Landai Kecamatan Tanah Sepenggal. Pelaksanaan kegiatan parenting menjadi orang tua kreatif untuk anak usia dini di masa pandemi covid 19 ini tidak lepas dari peran kepala sekolah, guru, dan yang paling utama adalah orang tua dalam membimbing anaknya selama belajar dari rumah. Tidak hanya itu, kegiatan pengabdian masyarakat dosen PIAUD Stai Ma'arif jambi juga mengadakan kegiatan prkatek langung orang tua dan anak dengan melaksanakan lomba kreativitas ibu dan anak dan motivasi yang dapat membuat mereka mampu memiliki pengetahuan dan pengalaman yang dapat menunjang kelancaran dalam efektifitas pembelajaran dari rumah selama masa pandemi. Seperti hasil pengabdian yang dilakukan oleh Fesilitas menyimpulkan bahwa perlu melibatkan orang tua dalam menstimulasi perkembangan anak agar berkembang optimal, satuan PAUD perlu memiliki sarana untuk menjalin komunikasi dengan orang tua dalam memantau perkembangan anak, orang tua dan guru bersama-sama menstimulasi perkembangan anak, bukan hanya menyerahkan tanggung jawab kepada guru PAUD, orang tua perlu menghabiskan waktu lebih banyak bersama anak di rumah melalui aktivitas bermain yang dilakukan bersama anak, satuan PAUD perlu menyusun program untuk melibatkan orang tua dalam kegiatan di satuan PAUD[17]. Penelitian lain menemukan bahwa 
evaluasi outcome dari program bina keluarga balita menunjukkan adanya kreatifitas orang tua yaitu orang tua membuat sendiri alat permainan edukatif, orang tua menggunakan media di dalam rumah dan orang tua berhasil dan berprestasi dalam menerapkan pola asuh yang baik serta memberikan contoh yang baik kepada masyarakat dalam menerapkan pola asuh yang benar bagi anak[18].

Dalam penelitian ini, peneliti memiliki analisis menyangkut kreativitas orang tua dan murid yang mengikuti pelaksanaan kegiatan parenting menjadi orang tua kreatif untuk anak usia dini di masa pandemi di PAUD ungu dusun lubuk landai yaitu dengan adanya kemampuan kreativitas orang tua dalam membimbing anak selama belajar dari rumah sesuai dengan permasalahan yang terjadi pada saat ini orang tua kurang memahami cara membimbing anak belajar dari rumah selama pandemi. Secara umum menjadi orang tua kreatif untuk anak usia dini dimasa pandemi covid19 melalui kegiatan parenting dan lomba kreatifitas ibu dan anak ini sudah berjalan dengan baik. Hal ini bisa peneliti lihat dari segi orang tua dan peserta didik yang begitu antusias dalam ikuti masing-masing rangkaian kegiatannya berupa materi, metode atau cara penerapannya dan media bermainnya yang menyenangkan. Peneliti juga mengamati bahwa peluang pelaksanaan kegiatan parenting dan lomba kreatifitas ibu dan anak ini sangat besar. Hal ini sejalan dengan belum pernahnya ada kegiatan seperti ini di PAUD Ungu Dusun Lubuk Landai Kecamatan Tanah Sepenggal.

\section{KESIMPULAN}

Diharapkan dengan adanya kegiatan peangabdin ini, akan menghasilkan orang tua kreatif di masa pandemi covid 19 ini dapat meningkatkan kreatifitas dan semangat orang tua dalam membimbing anak-anaknya belajar di masa pandemi ini. Meningkatkan kesadaran orang tua yang belum pernah mendapat materi cara menjadi orang tua kreatif dalam membimbing anak usia dini dalam proses tumbuh kembangnya di PAUD.. Hasil penelitian menyimpulkan tentang manfaatnya hasil pengabdian masyarakat ini adalah orang tua dapat menambahkan ilmu dalam bidang parenting tentang bagaimana menjadi orang tua yang kreatif dalam mengajarkan anak-anak mereka di rumah selama masa pandemi covid-19 ini. Menjadi orang tua yang kreatif yaitu dapat menciptakan lingkungan belajar yang menyenangkan dan kondusif, orang tua dapat dengan sabar memberikan stimulus berupa materi-materi yang diberikan oleh guru-gurunya.

\section{PENGHARGAAN}

Terima kasih disampaikan kepada seluruh pihak yang membantu terselenggaranya kegiatan ini. Pihak-pihak tersebut diantaranya adalah PAUD Ungu Dusun Lubuk Landai Kecamatan Tanah Sepenggal Kabupaten Bungo yang berpartisipasi aktif dalam kegiatan, serta seluruh panitia pelaksana baik Dosen maupun mahasiswa. 


\section{REFERENSI}

[1] E. Kurniati, D. K. Nur Alfaeni, and F. Andriani, "Analisis Peran Orang Tua dalam Mendampingi Anak di Masa Pandemi Covid-19," J. Obs. J. Pendidik. Anak Usia Dini, vol. 5, no. 1, p. 241, May 2020.

[2] A. Wardani and Y. Ayriza, "Analisis Kendala Orang Tua dalam Mendampingi Anak Belajar di Rumah Pada Masa Pandemi Covid-19," J. Obs. J. Pendidik. Anak Usia Dini, vol. 5, no. 1, p. 772, 2020.

[3] A. S. Akhyadi and D. Mulyono, "Program Parenting dalam Meningkat Kualitas Pendidikan Keluarga," Abdimas Siliwangi, vol. 1, no. 1, p. 1, Oct. 2019.

[4] J. Aris Try Andreas Putra, Sufiani, "Transformasi Nilai Pendidikan Islam Anak di PAUD Sultan Qaimuddin Kendari Pada Masa Pandemi Covid 19," Murhum J. Pendidik. Anak Usia Dini, vol. 1, no. 1, 2020.

[5] R. Tanjung, "Peran Orangtua dalam Pendidikan Anak Usia Dini di Masa Pandemi Covid-19," Murhum J. Pendidik. Anak Usia Dini, vol. 1, no. 2, pp. 64-73, 2020.

[6] J. M. Echols and H. Shadily, An English-Indonesian Dictionary. Cornell University Press, 2010.

[7] A. S. Horby, Oxford advanced learner's dictionary of current English. Oxford. Oxford University press, 2010.

[8] C. Monikasari, "Pelaksanaan program parenting bagi orang tua peserta didik di PAUD Permata Hati," Diklus, vol. 17, no. 1, 2013.

[9] T. Musfiroh, "Memilih, menyusun, dan menyajikan cerita untuk anak usia dini," Yogyakarta: Tiara Wacana, 2008.

[10] K. Maryani, "Penilaian dan Pelaporan Perkembangan Anak Saat Pembelajaran di Rumah di Masa Pendemi Covid-19," Murhum J. Pendidik. Anak Usia Dini, vol. 1, no. 1, pp. 41-52, 2020.

[11] R. H. Heru Kurniawan, "Program Parenting Untuk Membentuk Karakter Anak Usia Dini di Lembaga Pendidikan Anak Usia Dini," as-sibyan, vol. 1, no. 1, pp. 29-39, 2016.

[12] F. D. Andani, A. Rasyad, and M. I. Ihsan, "Manajemen Program Parenting Education Pada RA Al-Ikhlas Kepanjen Malang," J. Pendidik. Nonform., vol. 10, no. 2 september, pp. 139-150, 2016.

[13] L. A. Islamiyah, "Penerapan Perilaku Hidup Bersih dan Sehat Anak Usia Dini di Tengah Pandemi Covid 19," J. Obs. J. Pendidik. Anak Usia Dini, vol. 5, no. 1, pp. 463475, 2021.

[14] A. F. Nabila Fauziani, "Kreativitas Anak Melalui Kegiatan Mencetak Dengan Bahan Alam," JPP PAUD UNTIRTA, vol. 4, no. 2, pp. 125-135, 2017.

[15] S. Suriati, S. Kuraedah, E. Erdiyanti, and L. O. Anhusadar, "Meningkatkan Keterampilan Motorik Halus Anak melalui Mencetak dengan Pelepah Pisang," J. Obs. J. Pendidik. Anak Usia Dini, vol. 4, no. 1, p. 211, 2019.

[16] D. I. Yeni, H. Wulandari, and E. Hadiati, "Pelaksanaan Program Pemberian Makanan Sehat Anak Usia Dini : Studi Evaluasi Program CIPP," Murhum J. Pendidik. Anak Usia Dini, vol. 1, no. 2, pp. 1-15, 2020.

[17] F. Ndoet, P. Redy, P. Jaya, and B. Palmin, "Pelatihan Membuat Buku Penghubung Di PAUD Wejang Asih," Murhum J. Pendidik. Anak Usia Dini, vol. 1, no. 2, pp. 28-37, 2020.

[18] I. Islamiyah, F. B. Awad, and L. Anhusadar, "Outcome Program Bina Keluarga Balita (BKB): Konseling Orang Tua Dalam Tumbuh Kembang Anak Usia Dini," Zawiyah J. Pemikir. Islam, vol. 6, no. 1, p. 38, Jul. 2020. 